\title{
EVALUATION OF THE EFFECTIVENESS OF STRUCTURED TEACHING PROGRAMME REGARDING KNOWLEDGE ON PREVENTION OF GASTROENTERITIS AMONG MOTHERS OF INFANTS IN SELECTED HOSPITAL, BANGALORE, KARNATAKA
}

*Mrs. S. Anitha

*Ph. D Scholar\& Professor Yashoda College of Nursing, Saroornagar, Hyderabad, Telengana, India. DOI: http://doi.org/10.47211/tg.2020.v07iws01.007

Received $12^{\text {th }}$ June 2020, Accepted $18^{\text {th }}$ June 2020, Available online $30^{\text {th }}$ June 2020.

\section{ABSTRACT:}

Children are the most vulnerable group in any population due to their low immunity and large number cause's high mortality and mobility due to un hygienic practices at home, while weaning and feeding the child ${ }^{1}$. Globally out of 39 population, millions of children die due to dehydration and malnutrion ${ }^{2}$. A quasiexperimental study was undertaken to assess the effectiveness of knowledge on prevention of Gastroenteritis among Mothers of Infants in selected hospital, Bangalore', Karnataka was undertaken by among 60 mothers were selected by convenient sampling technique. The pre-test was taken by using structured knowledge questionnaire followed STP, post-test was conducted after 7 days the overall mean pre-test knowledge scores of mothers of infant was, 17.30 and the mean post-test knowledge scores of mothers 25.97 and ' $t$ ' value was $24.944(p<0.001)$. There was significant association found between the income and source of information and no significant was found with other demographic variables. Hence the finding of the study concluded that STP was effective in increasing the knowledge of mothers of infants regarding prevention and management of gastroenteritis. Hypothesis formulated were accepted.

KEYWORDS: Knowledge, mothers of infants, Prevention of Gastroenteritis, Structured teaching programme.

\section{ABOUT AUTHORS}

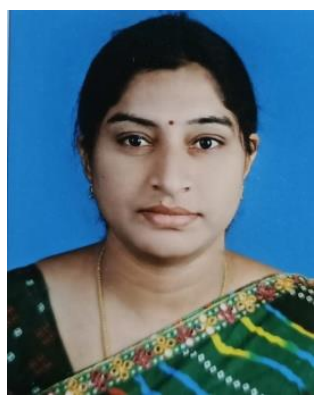

Author Mrs. S. Anitha is a Ph. D. Scholar. She is working as Professor in Yashoda College of Nursing, Saroornagar, Hyderabad, Telengana, India. 


\section{INTRODUCTION:}

\section{"Prevention is better than cure"}

Diarrheal disease remains a major public health problem in India. The major reasons attributable are poor environmental sanitation, broken drainage system, lapses in solid waste and night soil disposal and inadequacies in the preventive, promotive and curative aspects. The state has an extensive coastal belt with most favourable environmental factors for outbreak of diarrhoeal diseases especially during monsoon season. Incidence of diarrhoea is highest in the age group 6-11 months, when weaning occurs. A study conducted in India pointed out that a significant delay was observed in administering ORS/HAF, seeking medical help or implementing doctors' advice, in children suffering from diarrhoea in the lower class. This delay might be due to lack of awareness in the community, particularly among mothers. More than a quarter of the women felt that food should not be given during diarrhoea and many mothers believed that breast feeding should be stopped.

In small children, severe diarrhoea lasting just a day or two can lead to dehydration. Because a child can die of dehydration within a few days, the main treatment for diarrhoea in children is rehydration. According to recent reports, oral rehydration therapy many now is preventing about 1 million dehydration deaths a year.

Certain ways of food handling, preparation and storage practices increase the risk of faecal contamination. Diarrhoeal diseases are found to be more in the coastal areas, urban slums and tribal belts. Scarcity of safe water supply, practice of drinking water without boiling, high coliform organisms in the drinking water sources, improper disposal of human excreta, lack of protection from flies, practices of poor personal hygiene and food hygiene etc. are attributable to the outbreak of diarrhoea in these urban and rural community areas.

A study was conducted to develop in evidence and census based guideline for the management of the child who present to hospital with diarrhoea with or without vomiting. These finding conform the effectiveness of diarrhoea teaching with treatment unit (DTTU) strategy of ORT management of child with diarrheal dehydration combined with proper training and motivation of both mother and health worker, regarding prevention of gastrpemterotis at home. Since rotavirus diarrhoea is self-limiting disease, application of it should avoid treatment with antibiotics and consequently its hazards greater emphasis should be the management of this condition and home.

A study was conducted to evaluate the effectiveness of planned teaching programme on thermo regulation of neonates in terms of knowledge and practice of nursing personnel working in the labour room and neonatal care unit of selected hospitals of Kolkata. A structured knowledge questionnaire and an observation checklist were developed and utilized for data collection. The study reveals that the difference between pre and posttest knowledge scores of nursing personnel was significant at 0.01 level, $t[38]=20.71, p<0.01$. The difference between mean of pre-test and post-test practice scores was significant at 0.01 level, $t[38]=35.33, p<0.01$, indicating the effectiveness of STP. The correlation between knowledge scores and practice scores of nursing personnel was found significant. Whereas the relationship between knowledge scores and practice scores with selected variables was not found significant.

\section{STATEMENT OF THE PROBLEM:}

'Evaluate the effectiveness of structured teaching programme regarding knowledge on prevention of gastroenteritis among mothers of infants in selected hospital, Bangalore.'

\section{OBJECTIVES:}

- To assess the knowledge of mother on prevention of gastroenteritis, before STP.

- To evaluate the effectiveness of structured teaching programme on knowledge of mothers regarding Prevention of gastroenteritis among mothers of infants.

- To associate the post-test knowledge with selected demographic variables.

\section{HYPOTHESES:}

H1: There will be a significant difference between pre-test and post-test knowledge of mothers regarding prevention of gastroenteritis.

H2: There will be a significant association between the post-test knowledge on prevention of gastroenteritis among mothers of infants with selected demographic variables.

The conceptual frame work adopted for the study was from the general systems theory. It composed of three related major concepts of the theory they are input, throughout and output. This helped the investigator to evaluate the effectiveness of structured teaching programme on prevention of gastro enteritis and to assess the level of knowledge gained by the mother of infants.

\section{METHODOLOGY:}

In the methodology the investigator selected one group pre-test and a post-test design. The variables in the study are as follows:

Independent variable - Structured teaching programme on prevention of gastroenteritis. 


\section{ARTICLES}

Dependent variable - Knowledge of mothers of infants on prevention of gastroenteritis.

Attribute variable - Age, Education, Religion, Occupation, type of family, number of children source of information.

The structured interview schedule used for data collection was developed by the investigator which comprised of 2 sections. Section -1 contains demographic variables, Section -II consists of knowledge questionnaire about prevention of gastroenteritis.

Level of knowledge was assessed into 3 levels, adequate knowledge, moderate knowledge, inadequate knowledge. The structured teaching programme developed in a lesson plan method covers, the definition causes, signs and symptoms, types, diagnosis, management, treatment and prevention. The tool, structured teaching programme and AV. Aids were validated by 4 experts and found to be reliable and feasible. The test re- test was done for determining the reliability of tool. . The correlation co efficient was calculated using Karl Pearson method, $r=0.9$, was high positive.

Pilot study was conducted among 6 mothers of infants from Indira Gandhi child health nursing, Bangalore Main study was conducted among 60 mothers of infants from Indira Gandhi child health, Bangalore, during the month of July at the time period of 4 weeks. The convenient sampling was adopted to select samples based on selection criteria. The level of knowledge was assessed before teaching through administering pre-test by structured interview schedule; structured teaching programme was administered for 60 mothers of infants. After 7days post test was conducted.

RESULTS \& DISCUSSIONS:

The collected data was analysed and interpreted as per the objectives of the study by using descriptive and inferential statistical methods after careful editing, coding and transfer to computer, tabulating and decoding.

MAJOR FINDINGS OF THE STUDY:

Findings related to demographic variables of mothers of gastroenteritis:

Frequency and Percentage distribution of Socio Demographic Variables.

$\mathbf{N}=60$

\begin{tabular}{|c|c|c|c|}
\hline $\begin{array}{l}\text { Sl. } \\
\text { No. }\end{array}$ & $\begin{array}{l}\text { Background } \\
\text { Factors }\end{array}$ & Frequency Number & $\begin{array}{c}\text { Percentage } \\
\%\end{array}$ \\
\hline \multirow[t]{5}{*}{1.} & Age in years & & \\
\hline & $17-20$ & 7 & 11.7 \\
\hline & $21-25$ & 8 & 13.3 \\
\hline & $26-30$ & 33 & 55.0 \\
\hline & $31-35$ & 12 & 20.0 \\
\hline \multirow[t]{5}{*}{2.} & Education & & \\
\hline & Uneducated & 7 & 11.7 \\
\hline & Primary & 16 & 26.8 \\
\hline & Secondary & 27 & 45.0 \\
\hline & Graduate & 10 & 16.7 \\
\hline \multirow[t]{4}{*}{3.} & Religion & & \\
\hline & Hindu & 34 & 56.7 \\
\hline & Christian & 15 & 25.0 \\
\hline & Muslim & 11 & 18.3 \\
\hline \multirow[t]{3}{*}{4.} & Occupation & & \\
\hline & Daily wages & 21 & 35.0 \\
\hline & Skilled worker & 19 & 31.7 \\
\hline \multirow[t]{5}{*}{5.} & Income distribution & & \\
\hline & $<1000$ & 32 & 53.3 \\
\hline & $1000-2000$ & 13 & 21.7 \\
\hline & $2000-3000$ & 6 & 10.0 \\
\hline & $>3000$ & 9 & 15.0 \\
\hline \multirow[t]{3}{*}{6.} & Family type & & \\
\hline & Joint & 32 & 53.3 \\
\hline & Nuclear & 28 & 46.7 \\
\hline
\end{tabular}




\begin{tabular}{|r|c|c|c|}
\hline $\begin{array}{c}\text { S. } \\
\text { No. }\end{array}$ & $\begin{array}{c}\text { Background } \\
\text { Factors }\end{array}$ & Frequency Number & $\begin{array}{c}\text { Percentage } \\
\%\end{array}$ \\
\hline $\mathbf{7 .}$ & Number of children & & 53.3 \\
\hline & 1 child & 32 & 21.7 \\
\hline & 2 children & 13 & 10.0 \\
\hline & 3 children & 6 & 15.0 \\
\hline & $>3$ children & 9 & 10.0 \\
\hline $\mathbf{8 .}$ & Source of information & 6 & 28.3 \\
\hline & Friends \& Relatives & 17 & 23.3 \\
\hline & Health worker & 14 & 38.3 \\
\hline & News papers & 23 & \\
\hline & TV \& Radio & & \\
\hline
\end{tabular}

Distribution of demographic variables reveals that maximum number of mothers of infants $33(55 \%)$ were between the age group of 26-30,were in 26-30 years the least mothers 7 (11.7\%) mothers of infants belongs to17-20years and 21-25years are 8 (13.3) age group, and 12 (20.0\%) were in the 31 \&above years age group. With regard to educational status, majority $27(45 \%)$ mothers of infants were with secondary level, 16(26.8\%) were with primary level, $7(11.7 \%)$ were in uneducated level and $10(16.7 \%)$ of mothers of infants were with graduate level.

With regard to religion, majority 34 (56.7\%) of mothers of were Hind, 15(25.0\%) were in Muslim and least $11(18.3 \%)$ of mothers of infants were Christian religion.

With regard to occupation, majority $21(35.0 \%)$ of mothers infants were housewife and $19(31.7 \%)$ were skilled workers.

With regard to income majority of the mothers of infants belong to the family with income less than 1000rs, $32(53.3 \%) 13(21.7 \%)$ belong to families with income 1000 to $2000,6(10.0 \%)$ belong to family with income between $2000-3000,9(15.0 \%)$ belong to families with income more than 3000 .

With regard to type of family, majority of the mothers of infants were joint family $32(53.3 \%), 28(46 \%)$ belong to nuclear family.

With regard to number of children majority of the mothers were with one child32 (53.3\%), two children13 $(21.7 \%)$, and least were with three children 6 (10.0\%), 9 (15.0\%) were more than three children.

With regard to previous knowledge of information, majority 23 (38.3\%) of mothers of infants were through mass media, $6(10 \%)$ were by neighbours/ friends, $17(28.3 \%)$ were by health professionals.

Table 2 - percentage Distribution of Pre-test and post-test level knowledge score of mothers of infants regarding prevention of gastroenteritis

$n=60$

\begin{tabular}{|c|c|c|c|c|}
\hline \multirow{2}{*}{$\begin{array}{c}\text { Knowledge Level } \\
\%\end{array}$} & Frequency & Percentage $\%$ & Frequency & Percentage $\%$ \\
\cline { 2 - 5 } $\begin{array}{c}<50 \\
\text { Inadequate }\end{array}$ & 8 & 13 & 0 & 0 \\
\hline $\begin{array}{c}51-75 \\
\text { Moderate }\end{array}$ & 52 & 87 & 10 & 17 \\
\hline $\begin{array}{c}75 \\
\text { Above Adequate }\end{array}$ & 0 & 0 & 50 & 83 \\
\hline
\end{tabular}

The above figure 2 shows that the majority 52 (87\%) had moderate level of knowledge, whose score ranged between19-23, about $8(13 \%)$ of the samples had inadequate knowledge, whose score rang was less than 18 and about $0(0 \%)$ had adequate knowledge, whose score range was more than 27 in pre-test.

The above figure shows that the majority 50(83\%) had adequate level of knowledge, whose score range was more than 25 , about $10(17 \%)$ of the samples had moderate level of knowledge, whose score ranged between $16-23$ and $0(0 \%)$ had inadequate knowledge, whose score range was less than 15 in post-test. 


\section{ARTICLES}

Table 3: Evaluation of structured teaching program on Knowledge regarding the prevention of gastroenteritis among mothers of infants

\begin{tabular}{|c|c|c|c|c|c|}
\hline \multirow{3}{*}{ Questions } & \multicolumn{5}{|c|}{ Based on Correct answers } \\
\hline & \multicolumn{2}{|c|}{ Pre-assessment } & \multicolumn{2}{|c|}{ Post-assessment } & \multirow{2}{*}{$P$ value } \\
\hline & No & $\%$ & No & $\%$ & \\
\hline Q1 & 40 & 66.7 & 49 & 81.7 & 0.1704 \\
\hline Q2 & 36 & 60.0 & 55 & 91.7 & $0.0221 *$ \\
\hline Q3 & 45 & 75.0 & 53 & 88.3 & 0.2107 \\
\hline Q4 & 40 & 66.7 & 50 & 83.3 & 0.1471 \\
\hline Q5 & 37 & 61.7 & 53 & 88.3 & $0.0453^{*}$ \\
\hline Q6 & 29 & 48.3 & 51 & 85.0 & $0.0062^{* *}$ \\
\hline Q7 & 38 & 63.3 & 52 & 86.7 & $0.0687+$ \\
\hline Q8 & 27 & 45.0 & 50 & 83.3 & $0.0039 * *$ \\
\hline Q9 & 36 & 60.0 & 53 & 88.3 & $0.0326 *$ \\
\hline Q10 & 31 & 51.7 & 52 & 86.7 & $0.0097 * *$ \\
\hline Q11 & 29 & 48.3 & 51 & 85.0 & $0.0062^{* *}$ \\
\hline Q12 & 33 & 55.0 & 52 & 86.7 & $0.0185^{*}$ \\
\hline Q13 & 30 & 50.0 & 52 & 86.7 & $0.0068^{* *}$ \\
\hline Q14 & 35 & 58.3 & 53 & 88.3 & $0.0264^{*}$ \\
\hline Q15 & 35 & 58.3 & 53 & 88.3 & $0.0264 *$ \\
\hline Q16 & 28 & 46.7 & 53 & 88.3 & $0.0023^{* *}$ \\
\hline Q17 & 32 & 53.3 & 51 & 85.0 & $0.0173 *$ \\
\hline Q18 & 33 & 55.0 & 52 & 86.7 & $0.0183^{*}$ \\
\hline Q19 & 37 & 61.7 & 54 & 90.0 & $0.0365^{*}$ \\
\hline Q20 & 36 & 60.0 & 53 & 88.3 & $0.0348^{*}$ \\
\hline Q21 & 34 & 56.7 & 50 & 83.3 & 0.0199* \\
\hline Q22 & 39 & 65.0 & 52 & 86.7 & $0.0856+$ \\
\hline Q23 & 34 & 56.7 & 53 & 88.3 & $0.0199+$ \\
\hline Q24 & 34 & 56.7 & 51 & 85.0 & $0.0328^{*}$ \\
\hline Q25 & 32 & 53.3 & 51 & 85.0 & $0.0173^{*}$ \\
\hline Q26 & 37 & 61.7 & 51 & 85.0 & $0.0674+$ \\
\hline Q27 & 36 & 60.0 & 52 & 86.7 & $0.0428 *$ \\
\hline Q28 & 36 & 60.0 & 51 & 85.0 & $0.0529+$ \\
\hline Q29 & 33 & 55.0 & 54 & 90.0 & $0.0112+$ \\
\hline Q30 & 36 & 60.0 & 51 & 85.0 & $0.0529+$ \\
\hline Total score & \multicolumn{2}{|c|}{$17.30 \pm 1.66$} & \multicolumn{2}{|c|}{$25.97 \pm 2.41$} & $<0.001 * *$ \\
\hline
\end{tabular}




\section{ARTICLES}

Table 4: Evaluation of the Effectiveness of structured teaching programme on knowledge regarding prevention of gastroenteritis among mothers of infants.

\begin{tabular}{|c|c|c|c|c|c|c|}
\hline $\begin{array}{c}\text { Sl. } \\
\text { No. }\end{array}$ & Groups & Mean & $\begin{array}{c}\text { Standard } \\
\text { deviation }\end{array}$ & $\begin{array}{c}\text { Mean } \\
\text { difference }\end{array}$ & Paired 't' value & P-value \\
\hline 1. & Pre test & 17.30 & 1.66 & 8.67 & $\mathrm{t}=24.944$ & $\mathrm{P}<0.001^{* *}$ \\
\hline 2. & Post test & 25.97 & 2.41 & & \\
\hline
\end{tabular}

\section{** Highly significant $\mathrm{P} \leq 0.001$}

Reveals the mean, Standard deviation, and paired't' value of knowledge score regarding prevention of gastroenteritis in pre-test and post-test.

The obtained posttest mean value 25.97 was higher than the pretest value 17.30 . The mean difference between pretest and posttest was 8.67 and the obtained paired $t$ value is $24.944(p<0.001)$ was highly significant. Therefore hypothesis $\mathrm{H} 2$ was rejected and research hypothesis $\mathrm{H} 1$ was accepted. The mean value of posttest was significantly higher than the mean value of pretest.

It is inferred that mothers of infants had significantly gain in the posttest knowledge on prevention of gastroenteritis after structured teaching programme. The structured teaching programme was effective.

Table 5: Findings related to association between post-test knowledge on prevention of gastroenteritis and their selected background factors.

\begin{tabular}{|c|c|c|c|c|c|}
\hline S.No. & Age in years & Number & Mean & $S D$ & ANOVA \\
\hline 1. & $17-20$ & 7 & 9.00 & 1.83 & \multirow{4}{*}{$P=0.659$} \\
\hline 2. & $21-25$ & 8 & 8.75 & 2.55 & \\
\hline 3. & $26-30$ & 33 & 8.30 & 2.49 & \\
\hline \multirow[t]{2}{*}{4.} & $31-35$ & 12 & 9.42 & 3.70 & \\
\hline & Education & & & & \\
\hline 1. & Uneducated & 7 & 7.86 & 2.12 & \multirow{4}{*}{$P=0.068$} \\
\hline 2. & Primary & 16 & 7.94 & 3.15 & \\
\hline 3. & Secondary & 27 & 8.59 & 2.44 & \\
\hline \multirow[t]{2}{*}{4.} & Graduate & 10 & 10.60 & 2.27 & \\
\hline & Religion & & & & \\
\hline 1. & Hindu & 34 & 8.18 & 2.78 & \multirow{3}{*}{$P=0.145$} \\
\hline 2. & Muslim & 11 & 10.00 & 2.45 & \\
\hline \multirow[t]{2}{*}{3.} & Christian & 15 & 8.80 & 2.46 & \\
\hline & Occupation & & & & \\
\hline 1. & Daily wages & 21 & 9.38 & 2.64 & \multirow{3}{*}{$P=0.265$} \\
\hline 2. & Skilled worker & 19 & 8.00 & 3.19 & \\
\hline 3. & House wife & 20 & 8.55 & 2.11 & \\
\hline
\end{tabular}




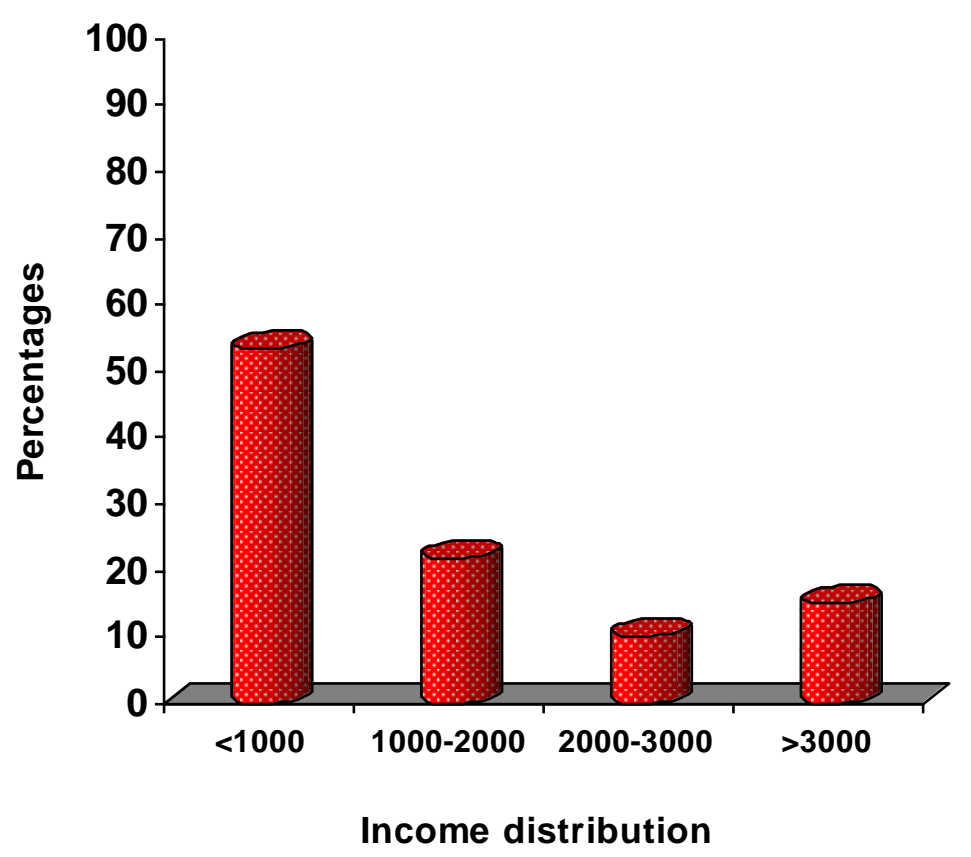

Figure 1: Income distribution

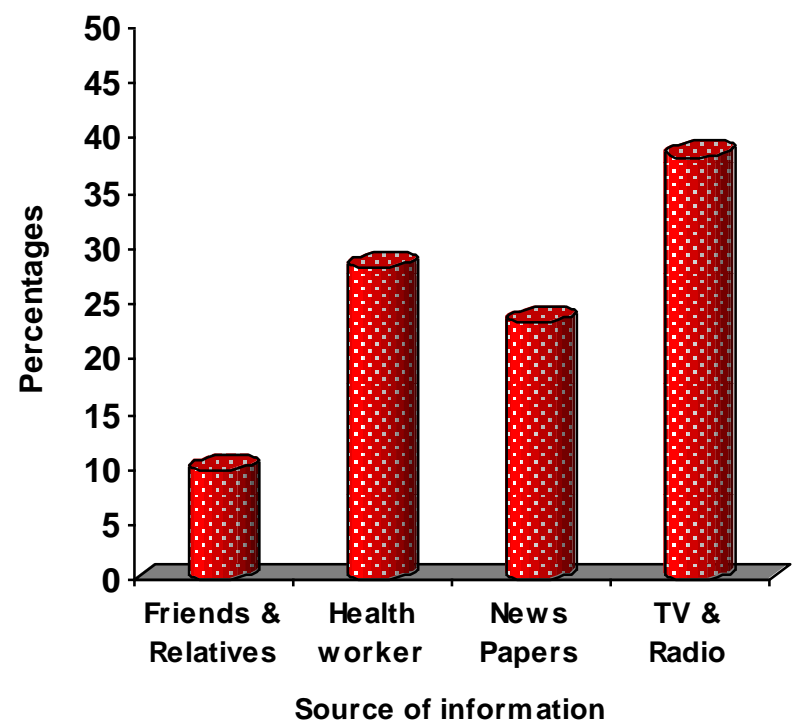

Figure 2: Source of information.

Figure 1 and 2 represents association between post-test knowledge of mothers of infants with selected demographic variables such as Age, Education, Religion and Occupation which does not show any statistically significant association with the post-test knowledge of mothers of infants.

- There was no significant association between the age of mothers of infants and their post-test knowledge score on prevention of gastroenteritis. ANOVA value $f 0.0659(P>0.05 \%)$. The gain in posttest knowledge score was independent of age of mothers of infants.

- There was no significant association between the education of mothers of infants and their post-test knowledge score on prevention of gastroenteritis. ANOVA value $f=0.068$ ( $P>0.05 \%)$. The gain in posttest knowledge score was independent of education of mothers of infants. 
- There was association between Religion and post-test knowledge on prevention of gastroenteritis. The obtained ANOVA value=0.145 was not significant at $\mathbf{0 . 0 5}$ levels; a gain in post-test knowledge score was independent of religion of the mothers of the infants.

- Shows the association between Occupation and post-test knowledge on prevention of gastroenteritis. The obtained ANOVA value $=\mathbf{0 . 2 6 5}$ was not significant at $\mathbf{0 . 0 5}$ levels; a gain in post-test knowledge was independent of occupation of the mother's of infant.

- Shows the association between income and post-test knowledge on prevention of gastroenteritis. The obtained ANOVA value $\mathbf{0} \mathbf{0 . 0 0 2}$ was significant at $\mathbf{0 . 0 5}$ levels, therefore hypothesis $\mathrm{H} 2$ was accepted. It is inferred that there was a significant association between income and post-test knowledge score. The gain in post-test knowledge was dependent on income of mothers of infants.

- Shows the association between score of information and post-test knowledge on gastroenteritis. The obtained ANOVA value $\mathbf{0} \mathbf{0 . 0 0 2}$ was significant at $\mathbf{0 . 0 5}$ levels, therefore hypothesis $\mathrm{H} 2$ was accepted. It is inferred that there was significant association between the source of information and post-test knowledge score. The gain in post-test knowledge was independent to age of mothers of infants.

\section{NURSING IMPLICATIONS:}

The study finding have several implications in the field of community health nursing, paediatric nursing service, nursing administration, nursing education and nursing research.

Limitations: Only limited sample size was taken because of time constraints -60 mothers of infants admitted in Indira Gandhi Children's Hospital.

The study was conducted for a short period only

RECOMMENDATIONS:

Similar study can be replicated in a large scale to -

- Assess the practices of mothers with multiple observations.

- Other age groups.

- Assess the prevalence of diarrhoea among under-fives in the community.

\section{CONCLUSION:}

The present study concluded that structure teaching programme was affective in improving knowledge regarding prevention of gastroenteritis among mothers of infants in selected hospital, Bangalore, Karnataka.

\section{REFERENCES:}

1. Marlow,R Dorothy,Textbook of Pediatric Nursing .Philadelphia: W.B.Saunder's Company 2005. 569.

2. SurajGupta short textbook of Preventive Pediatrics.10 ${ }^{\text {th }}$ ed.new Delhi:Jayape;2004:7.

3. Wong's. Nursing care of infants and children. $7^{\text {th }}$ ed.new Delhi:Eleseiver Pvt Ltd:2006:1167-1170.

4. Kasturi sunder Roa. An introduction to Community Health Nursing. $4^{\text {th }}$.ed. Chennai publisher's private limited: 2004:502-507

5. Vishwanathan J,Desari.B,Achars; Textbook of pediatric,Hyd1989;416 - 486.

6. Cicely , D Williams, Mother and Child Health Services. ELBS Oxford University Press ,1991,16-19.

7. K. Park essentials of preventive and social medicine, $19^{\text {th }} \mathrm{Ed}, \mathrm{M} / \mathrm{s}$ Banarsidas Bhanot Publication 2007, 457-460.

8. Pilot, Denise, and Bernadette, P. Hungler, Nursing research - principles and methods; J. B. Lippincott Company, 1995.

9. Sangupta B, Dasgupta S, Saha I. The diarrheal training cum treatment unit of NRS medical college and hospital, Calcutta. J Ind med. 1999; 96(4): 104-108.

10. Kamala. Management of Diarrhea in DTU. Indian Paediatrics:1996, 33 (10):856- 859 